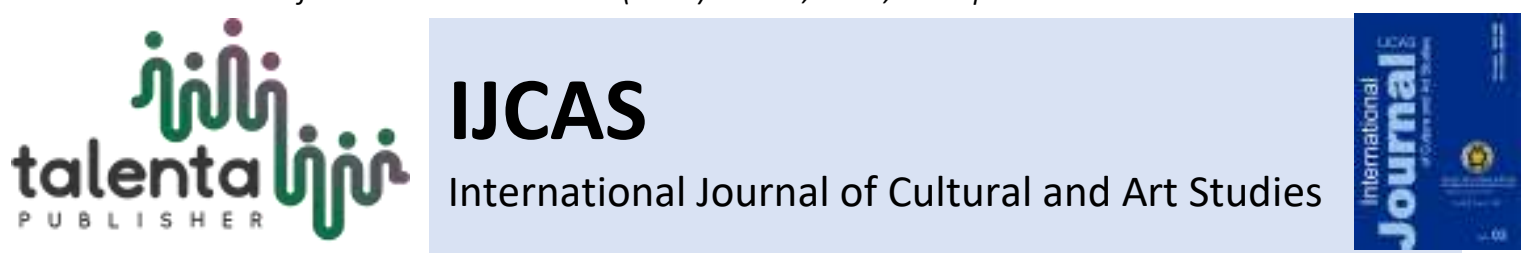

\title{
Stepping Out of The Cultural Identity: A Critical Analysis of Cathy Song's Memory Poetry
}

\author{
Winda Setia Sari* \\ English Department, Universitas Negeri Medan, Medan, Indonesia.
}

\begin{abstract}
Cathy Song, a Chinese-Korean ancestry woman poet, grew up in Hawaii, America. In "What Belongs to You", a poem taken from her second poetry publication, she chronicles the memory of a child who is trapped between her dream and devotion. The theme of the poem is portrayed in a strong poetic devices. The poems lean in vivid visual imageries to evoke to the poet's life memory. The speaker of What Belongs to You dreams of having the freedom and attempts to escape from her parental tie. Ironically, she finds herself devote to her family and tradition. The poems use past materials ranging from domestic domain and landscape which define the speaker's personal memory. Comparing than Cathy's Song first poetry publication, arguably, the cultural materials in the poem cannot be traced through Song's poetic devices as an ethnic woman poet. In fact, song locates the dream and devotion in visual imageries and nostalgic tones in a general way. This is true; Song has denied herself as a cultural visionary. Song merely mines the memory from the point of view and identity of a woman, leaving her cultural traits behind.
\end{abstract}

Keyword: Memory, Poetry, Cultural Identity, Imagery

Received 10 March 2019| Revised 26 April 2019| Accepted 29 April 2019

\section{Introduction}

The art of poetry has capacity to conjure memory's power [1]. In other words, the creation of a poem is sometimes inspired by the act of remembering things from the past. Poetry is so often undoubtedly connected to memory.

It is Cathy Song, a Chinese-Korean ancestry woman poet, who wrote the memory of her maternal culture. She has recollected specific events from the past giving the poems the details on her personal and family history. As asserted by Cullum, Song's writing certainly deals with her ethnicity, song found characters whom she could recognize in her own life [2]. The first collection of Song poetry, Picture Bride, was known as the album of her family history, her communal portraits. Similarly, Fujitasato [3] confirmed that Song's poems are the portrayal of specific places and history and at the same time a portrayal of cultural synthesis and pluralism.

\footnotetext{
*Corresponding author at: English Department, Uniersitas Negeri Medan, Jl. Willem Iskandar Pasar V Medan, Medan city, Indonesia. 
Thus, her personal and family history is presumably considered as valid cultural material for her poetry.

What arguable in the collection of Song Poetry is the cultural materials are not often sturdily delivered. Lim pointed out that Song's repeated use of these Asian cultural fragments is strained, mechanical, and unconvincing [4]. Lim has countered some critics upon Song's total representation of Asian American experience through cultural synthesis. Lim asserted that Song writes most deeply when she gives up her concern with surface ethnic-coloristic effects and concentrates on the details of her world, her vision, in whose singularity we can all recognize ourselves (99).

After exploring What belongs to you, a poem taken from Song's second poetry collection, I personally identified what has been hypothesized by Lim. Especially when it comes to the matter of describing the memory of Mother-Daughter, parental tie and the kinship motif. Cathy Song's writing uses strong visual imagery of the everyday objects to describe the past [2]. However, the past materials lean in a more general and universal matters. Through vivid visual image, Song evoked her own memory in such a way that makes readers able to identify the distance between her poetry and her ethnicity, her cultural identity.

Excavated from some universal images of landscape and domestic domain which is supported by the voice of a child speaker with an adult consciousness in the poem, this article attempts to discuss the isolation of speaker-poet from her cultural identity when drawing the childhood memory; the memory is built in strong poetic devices, yet away from Song's cultural material.

\section{Cathy Song's First Collection of Memory Poetry: Picture Bride}

In fact, many critics have formulated a hypothesis of Picture Bride as the writing that deals with Song's ethnicity. She further argues that an overarching theme in Song's work is that of family relationship; she writes of the ties between parent and children (2012). From this assertion, a deeper analysis of one poem taken from Picture Bride has been conducted and it is found that the character in the poem is strongly tied to her tradition and family; her maternal culture.

In "The Youngest Daughter", most popular poem in the collection, the 'speaker poet' found herself trapped between the tradition and the desire to escape from the figures of a sickly mother. The theme is obviously described in the last 5 lines of the poems :

She knows I am not to be trusted

even now planning my escape.

As I toast to her health 
with tea she has poured,

a thousand cranes curtain window,

fly up in a sudden breeze.

(From Picture Bride, 1982)

"Escape" motif is the recurrent theme in Song poem. This autobiographical content of Cathy clustered around the attempt of a speaker poet to break from the maternal ties and cultural tradition. Yet the escape in Song's poems is always subjugated by the sense of devotion 'speaker poet' felt about her family, her mother and her home.

What is more interesting about Song's Picture Bride is the poetic of maternal culture and tradition which clearly become the strong point to declare Song's cultural identity as an Asian Woman poet.

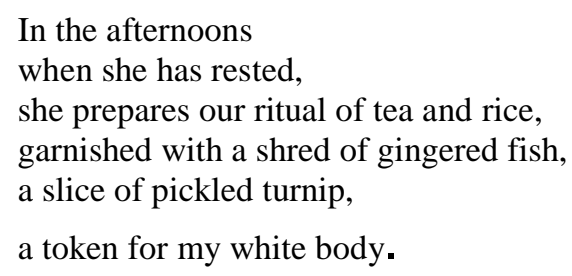

The images Song render in her memory poem such as pale as a rice paper, ritual of tea and rice, a shred of gingered fish mixed with vivid Hawaian landscape represent herself as a poet with Asian element of identity.

\section{The Imagery of Memory on Dream and Devotion which is away from Cultural Identity}

Memory poems that that are accompanied by strong visual imagery often persuade us that they are based on the poet's actual experience [1]. Cathy Song is categorized here as an imaginary writer, one who cooperates images and evokes the memory in her poetry. In her poem entitled What Belongs to You, Song creates the images of dream and devotion by building strong visual imagery. The poem begins with the poet speaker identification on the image of river that resonates speaker's dream.

There was a river in you

Small and dark,

Unseen behind the trees,

The morning you left the house,

Your Mother, at last asleep 
The speaker in this poem is the second speaker (you) presented in a child's voice with an adult consciousness. Song saliently uses some visual images which are apparently distant from her identity as an Asian American ethnic poet. River, tree, house are poetic places and objects representing the speaker's dream and escape. The cultural artefacts in this collection suddenly disappear from the poems. Song's linguistic choice clearly split the gap between the poet and her identity.

The image of river represents speaker's desire to cross from one place to the specific place. From the place where the mother at last asleep to a new place which is described as speaker's dream. The desire to reach the new place is undeclared by the speaker to her parents (unseen behind the tress). The dream itself is weak, pessimistic and not fully determined. The images of small and Dark River characterize this kind of dream.

Another image of dream conveyed in the poem is the image of Kite. The image of kite is associated with the dream that was supposed to fly high, but ironically the speaker unable to fly the kite since the image of the kite is incomplete without the image of the string. The image of the kite pinned to your shoulder metaphorically conveyed speaker's inability to escape from her family particularly from the figures of her parent. A kite is supposed to fly but not to pin. The restrained dream is conveyed through the image of a pinned kite.

Again, Song used the theme of Escape in her poem, in this case, to escape means to reach one specific place away from the maternal life. The dream to be somewhere else is started to be pursued eventually by sailing (you sailed unnoticed into the trees). Yet the act of sailing seems hard since it not as strong and fast as flying.

Meanwhile, devotion which restrains the dream is characterized by the image of the house, fourteen doors, a window and a map. As confirmed by Hetherington that the role of imagery particularly visual imagery is often crucial because imagery allows readers to 'see' a particular poetic location and imagine themselves there (2012). Home with all kind of attributes is the poetic location to signify speaker's devotion. These images of domestic domain strongly support the idea of devotion. The speaker found herself tied to home by recollecting specific images from the past (A map you could trace). A map is signified as the device to see the poetic location, to recollect things and to point out the condition that strengthens the idea of devotion. The map pointed out to the home and all the surrounded objects.

Another strong imagery which conveys the dream detained by devotion is the wind. Often the speaker mentions wind to unfold the reverse of dream into devotion. 
Unnoticed, you sailed into the trees

where the pull of the wind

could release your name like a kite;

calling your self home ...

until it flew back

The strength of wind represents the bound between parent and child; the most dominant spiritual motif that makes speaker decide to come back (calling your self home.. until it flew back).

The landscape image which is the tree in the last line of the poem ironically end speaker's dream to escape from the parental ties. The Speaker is eventually heading back to the place that belongs to her, her family. The picture of a boy falling out the tree emphasizes the idea of giving up the dream.

The poet speaker saliently used some visual images which are apparently distant from her identity as Asian American ethnic poet. River, kite and tree are poetic places and objects representing speaker's dream. While doors, windows, map and the wind portray speaker devotion that has long bound her to her family. The dream and devotion are present exteriorly in the domestic domain and landscape. However, the images are universal and general, exist without the cultural artefacts. None of the images can be identified having colouristic effects of Asian American culture.

\section{Conclusion}

In contrast to what Cathy Song has built in her first collection, Picture Bride, Cathy Song, in the second collection seem deconstructs the image of ethnic poet as a cultural visionary. She creates some memory poems which are remote from her cultural material. In her poem entitled "What Belongs to You", Song works again with the escape motif, but this time, she creates the images of dream and devotion by building strong visual imagery. She used second person narration and male character dominancy. Also, at this point, universal and undistinctive element in Song's "What belongs to you is discovered. Clearly, Asian American poetic identity is not powerfully manifested in Cathy Song's second poetry collection

Maftei pointed out that identity is not static within the same person and how the passage of time can disconnect the author and his or her identity as it appears in the text as well as from his/her past (2013). This perhaps may answer the problematic questions about Song's second poetry collection. She reinvents ways of recalling moments and has been caught in the act by some critics for creating a distance between herself and her Asian Americans heritage. Time and space have rendered the way Cathy Song performs her written discourse; between the first and second poetry collection, Song has evoked a contrast in her poetic choices. Bloom in Xiojing 
argued that the poetic tradition is preserved and renewed through "the life-cycle of the poet -aspoet" (2007). This statement is robust, and it is the answer for Song's case.

\section{REFERENCES}

[1] Hetherington, Paul. The Past Ahead: Understanding Memory in contemporary Poetry. International Journal for the practice and Theory of Creative Writing. Vol 9, No 1(2012): 102-115.

[2] Cullum, Linda. The Poets : Cathy Song . Contemporary American Ethnic Poets : Lives, Works, Sources Westport, Conn : Greenwood Press. 2004.

[3] Fujita-Sato, Gayle K. 'Third World' as Place and Paradigm in Cathy Song's Picture Bride." MELUS 15 (1988): 49-72.

[4] Sherley, L. Picture Bride by Cathy Song: Review, Vol. 10, No. 3, Varieties of Ethnic Criticism (Autumn, 1983), pp. 95-99.

[5] Allan. Burns, Thematic Guide to American Poetry, Westport, Conn: Greenwood Press, 2002.

[6] Bloom Harold in Zhou Xiaojing, "Breaking From Tradition: Experimental Poems by Four Contemporary Asian American Women Poets". Revista Canaria de Estudio Ingleses, No 37, page 199-218, 1998.

[7] Song, Cathy, Frameless Windows, Squares of Light, New York: W.W. Norton, 1988.

[8] Song, Cathy, Picture Bride, Yale : Yake University Press. 1983.

[9] F. Chen, Body and Female Subjectivity in Cathy Song's picture Bride, Woman 's Studies 33:577-612 (2004): 577-612. 